\title{
EKONOMI KERAKYATAN VERSUS EKONOMI LIBERAL DALAM PANDANGAN FIQH MUAMALAH
}

\author{
Singgih Muheramtohadi \\ FEBI UIN WALISONGO SEMARANG
}

Singgih.muheram@gmail.com

\begin{abstract}
The Debate between neoliberalism thought and populist economic thought is concerned by public attention. The interesting thing on this dcebate is the both of them have the different paradigm and have a big influence in public decision making. This paper discuss what are these paradigms, how it was formaed in the history backgrounds, which the juridical foundations to legalize the thinking, and what the figh views. This paper use description and analytical method. The result the discuss, that populist economic thought is closer to islamic view than the neoliberalism though in that he populist thought stands on conscience. And the concscience is one of the fiqh substances, especially concerning about economical relation.
\end{abstract}

Keyword : populist, neoliberalism, paradigm, fiqh

\section{A. Pendahuluan}

Akhir-akhir ini publik dikagetkan dengan wacana perdebatan antara dua ekonom ternama di Indonesia, yaitu Dr Rizal Ramli vs Dr Sri Mulyani. Keduanya mewakili dua aliran besar dalam ekonomi Indonesia, yaitu aliran Ekonomi Kerakyatan, dan aliran Ekonomi Pasar Bebas atau Neoliberalisme. perdebatan ini, jika terjadi, hanyalah fenomena 'gunung Es'. Karena, konteks perdebatan ini pada dasarnya sangat luas, mencakup paradigma dan sejarah pemikiran antara keduanya yang tidak mungkin mencapai titik temu.

Mdnurut Moebyarto (2014 :153)Gambaran negatif sering diberikan oleh kelompok Ekonomi Kerakyatan kepada kelompok Ekonomi Neoliberal. Seperti gambaran Sri Edi Swasono, yang menggambarkan ekonomi Neoliberal kapitalistik adalah proses ekonomi yang digerakkan oleh homoecomictus, atau makhluk ekonomi yang rakus dengan insting mencari kepuasan dan keuntungan maksimal. Sedangkan gambaran ekonomi kerakyatan, digambarkan sebgai homo socius, yaitu makhluk sosial yang menjaga kerukunan antar sesama dan bekerjasama demi kepentingan bersama. Homo socius menurut Edi Sri Swasono, cenderung menjadi homoreligious, karena mereka mengemban etika dan saling tolong menolong, bukan saling bertarung memenangkan persainganJika kita menengok secara obyektif, maka rata-rata ekonom berpaham kerakyatan 
melandaskan pemikiran pada kekhawatiran akan kondisi bangsa indonesia, ke depan. Kekhwatiran akan terkuasainya segala sumberdaya alam yang ada di Indonesia oleh kekuatan oligopoli ekonomi dari korporasi-korporsi besar. Hal ini ditunjukkan dengan meningkatnya Rasio Gini Indonesia dari tahun ke tahun (Moebyarto, 2014, hlm. 133), yaitu : 0.35 (2008), 0.37 (2009), 0.38 (2010), 0.41 (2011), 0.41 (2012), dan 0.413 (2013)

Tingkat ketimpangan ini, adalah terbesar nomer empat di seluruh dunia. Sedangkan ekonomi liberal pemikiran didasarkan atas keyakinan, bahwa 'tangantangan ajaib' akan bekerja, sehingga jika penawaran terhadap komoditas maupun permintaan terhadap komoditas, mencapai titik keseimbangan, maka semua lapisan masyarakat akan merasakan hasilnya.

Paham Ekonomi Kerakyatan dan Neoliberalisme tidak lah muncul dari ruang hampa. Ia muncul dari aspek kesejarahan. Dalam realitasnya, pengaruh paham tersebut besar dan berada di balik tiap pengambilan kebijakan pemerintahan. Sehingga menarik kiranya, jika mengkaji dua pemikiran yang bertentangan ini, dengan menyibak latar belakang sejarah, produk hukum apa saja yang dihasilkan dari keduanya, dan kebijakan apa yang dipengaruhi oleh keduanya. Dan tidak kalah penting adalah bagaimana pandangan fiqh islam, terhadap dua paham ekonomi tersebut.

\section{B. Metode}

Jenis penelitian yang digunakan dalam tulisan ini adalah penelitian pustaka. Dimana sumber data yang digunakan oleh peneliti berasal dari tulisantulisan yang tersebar dalam jurnal maupun buku Ekonomi Makro, ataupun sumber kepustakaan lainnya yang relevan. Penelitian menggunakan Metode Deskripsi dan Analisa. Deskripsi menggambarkan obyek studi yang akan dibahas. Dan Analisa adalah menguraikan berbagai unsur yang ada didalamnya.

\section{Pembahasan}

\section{Tinjauan Fiqh terhadap Interaksi Ekonomi}

Pembahasan Ekonomi dalam fiqh dibahas pada Bab Muamalah yang berisi ketentuan umum interaksi antara ummat islam dengan orang lain.ilmu ekonomi islam menggunakan fiqh muamalah sebagai salah satu kerangka normatifnya(Suharto, 2004:42) , sehingga aspek-aspek muamalah seperti kejujuran dan tolong menolong masuk sebagai etika ekonomi dalam islam.

Beberapa aturan fiqh terkait ekonomi secara umum, dapat dilihat pada beberapa list berikut ini(Taqwa, 2008 : 94); 
dalam Jual beli diharamkan melakukan penipuan atau tadlis, dengan mengurangi takaran timbangan.

1. Dalam jual beli dilarang melakukan penimbunan barang komoditasuntuk keuntungan pribadi, yang berdampak pada instabilitas harga dipasar.

2. Dalam bermuamalah dihalalkan untuk melakukan perniagaan, tetapi diharamkan melaukan praktek riba.

3. Dalam praktek jual beli, tidak diperkenankan melakukan transaksipada barang gharar, atau barang yang tidak diketahui wujud ataukualitasnya secara pasti baik oleh pembeli ataupun penjual.

4. Dalam hal penguasaan faktor produksi, islam menghalalkanpenguasaan terhadap alat produksi dan kepemelikan lahan.

5. Kepemilikan terhadap faktor produksi di atas, tidak diperkenankanpada kepemilikan SDA (Sumberdaya Alam ) yang menentukan hajathidup orang banyak,

6. Seseorang tidak diperkenankan memiliki harta kekayaan berlimpahtanpa mempedulikan nasib orang-oorang di sekitarnyaserta wajibmengeluarkan zakat dan shodaqoh .

7. Seorang pemimpin tidak diperkenankan untuk mempengaruhi hargapasar, yang tidak terdapat praktek kecurangan di dalam nya.

\section{Ekonomi Kerakyatan vs Neoliberalisme}

a. PengertianPaham Ekonomi Kerakyatan \& Liberalisme

Menurut Moebyarto (2014 : 155) Ekonomi Kerakyatan adalah Ekonomi yang berasas kekeluargaan, berkedaulatan rakyat, bermoral Pancasila, dan menunjukkan pemihakan sungguh-sungguh pada ekonomi rakyat (Bhudianto, 2012 : 4). Yang dimaksud dengan 'ekonomi rakyat' sendiri adalah usaha yang dilakukan oleh rakyat kebanyakan(popular) secara swadaya, yang ditujukan untuk memenuhi kebutuhan dasaranggota keluarganya. Sehingga, subyek dari ekonomi 
kerakyatan meliputi banyak hal, yaitu UMKM, sektor pertanian/peternakan, kerajinan dan jasa, atau seringdisebut dengan sektor informal.

Menukil pendapat dari Prof Hidayat dari Universitas Padjajaran Bandung (Unpad), I Made Sukarsa menyatakan beberapa ciri dari sektor informal, yaitumeliputi(Sukarsa 2010, hlm. 4):

1) Usaha berskala kecil,

2) Tenaga kerja berasal dari keluarga, kerabat atau tetangga, yangtidak terdaftar dan tidak perlu ijin formal.

3) Usaha tidak masuk dalam daftar pajak, karena kecilnya labayang dihasilkan.

4) Tidak mempunyai akses ke lembaga keuangan sebagai pemasok modal.

Terdapat banyak varian definisi tentang ekonomi kerakyatan,diantaranyayang paling 'ekstrim' adalah pendapat bahwa Ekonomi kerakyatan adalah suatuproses ekonomi yang berupaya memindahkan kedaulatan ekonomi dari oligarki ke tangan seluruh anggota masyarakat(Moebyarto, $2014: 33$ ). selain terdapat varian definisi tentang ekonomi kerakyatan, terdapat pula banyak penamaan. Selain "ekonomi kerakyatan" juga sering disebut dengan "Ekonomi Demokrasi" atau sebagian ekonom Indonesia, menyebutnya dengan "Ekonomi Pancasila" .

Lawan dari Sistem Ekonomi Kerakayatan adalah Sistem Ekonomi Neoliberalisme. Paham Neoliberalisme berasal dari kata Neo yang berarti kebangkitan kembali, dan liberalisme berasal dari kata liberal yang artinya kebebasan. Paham liberal berasal dari perkembangan falsafah Eropa Barat padaabad ke 18 dan 19, yang memandang manusia mempunyai otonomi dan kekebasan menentukan nasibnya sendiri, baik secara politik maupun secara ekonomi(Saphiro, 2006:236). Di bidang politik berpengaruh pada terjadinya demokratisasi di sejumlah negara Eropa, dan di bidang ekonomi berpengaruh pada penguasaan lahan dan industri manufaktur di luar kepemilikan kerajaan (tanah feodal).

Sedangkan secara istilah Ekonomi Neo Liberalisme adalah paham ekonomi yang mengutamakan sistem permodalan, perdagangan bebas, dan kebebasan dalam hal kepemilikan (termasuk kepemilikan atas suatu barang yang penting dan menguasai hidup orang banyak), penghilangan campur tangan pemerintah, dan mengurangi peran pemerintah dalam pelayanan publik, seperti pada bidang ekonomi (pemberian kredit lunak), pendidikan (seperti program pendidikan 
gratis), kesehatan (termasuk program BPJS) dan sebagainya. Sehingga ciri dari kebijakan Ekonomi Liberalisme meliputi(Faqih, 2003 : 105)

1) Pemudahan akses terhadap investasi, baik asing maupun domestik, dengan cara menghapus segala jenis hambatan, termasuk pada hambatan perijinan dan sebagainya.

2) Membuka keran selebar-lebarnya bagi masuknya komoditas dan investasi asing, termasuk pada kepemilikan lahan dan faktor produksi oleh investor asing. Termasuk pada hambatan bea masuk terhadap barang dari luar.

3) Penjualan aset-aset BUMN , serta hak penguasaan terhadap aneka jenis tambang dan sumberdaya listrik.

4) Pencabutan segala jenis bantuan terhadap warganegara, baik bantuan berupa modal, bantuan sosial, maupun bantuan dalam bentuk subsidi.

\section{b. Tinjauan Fiqh Terhadap Paradigma Ekonomi Kerakyatan \& Neoliberal}

Dilihat dari definisi dan ciri-ciri di atas, maka perbedaan terpenting dari paham Neoliberalisme dan Paham Kerakyatan terletak pada proteksi (perlindungan) dan Penguasaan terhadap sumberdaya alam. Penguasaan atassumberdaya alam oleh Negara, mengasumsikan bahwa jika hal itu dikuasai oleh swasta maka akan rentan terjadi monopoli. Praktek ini juga sudah ada sejak masa silam termasuk pada masa kehidupan rasulullah di Madinah.

Kisah Sumur Usman atau Sumur Rauma, merupakan sebuah cerita yang menarik yang menceritakan tentang seorang Yahudi yang menguasai sebuah sumur, dimana sumur tersebut satu-satu nya sumur yang dimiliki oleh penduduk Madinah. Setiap kali orang memanfaatkan sumur tersebut, maka akan dikenai biaya tinggi. Maka Rasul bersabda: Wahai sahabatku, Barangsiapa yang mengeluarkan harta bendanya, kemudian membebaskan sumur tersebut, dan memberikan kepada orang banyak, maka balasan baginya adalah surga (HR Muslim).Dari banyak kisah tentang kehidupan rasulullah dan para sahabat, tidak ada satu pun jejak yang menghalalkan segala bentuk penguasaan barang milik secara serakah dan untuk kehidupan nya semata. 


\section{b. Sejarah Ekonomi Kerakyatan\& Neoliberalisme}

\section{1) Kemunculan Pemikiran Ekonomi Kerakyatan}

Pembahasan tentang "ekonomi kerakyatan" penting untuk menengok bagaimana istilah ini muncul dalam perdebatan ekonomi akhir-akhir ini. Karena paham 'ekonomi kerakyatan' sangat dekat dengan sejarah pergolakan bangsa indonesia itu sendiri. baik pergolakan dengan kaum kolonial, penetapan landasan yuridis oleh Undang-undang Dasar 1945 serta falsafah Negara (Pancasila) yang berhaluan ekonomi kerakyatan, dan diikuti oleh kebijakan-kebijakan pemerintahan sesudahnya (yaitu pada masa Soekarno). Terdapat pasang surut pergumulan pemikiran ekonomi kerakyatan, baik diakibatkan oleh faktor internal (faktor polirik dalam negeri) maupun faktor ekstrenal (tekanan luar negeri) sebagaimana yang dilihat pada sub bab berikutnya.

Istilah ekonomi kerakyatan dipopulerkan oleh Muhammad Hatta jauh sebelum kemerdekaan. Yaitu ketika awal tahun 1930an yang menulis beberapa tulisan, diantaranya adalah(Hoesein, $2006: 505)$ :

a) Pengaroh Kolonial Kapital di Indonesia, dimuat pada 20November 1931.

b) Ekonomi Ra'jat, dimuat pada 20 November 1933

c) Ekonomi Ra'jat dalam Bahaya, yang dimuat pada tangggal 10Juni 1934

Semua tulisan tersebut terdorong atas keprihatinan atas kebijakan ekonomi yang diterapkan oleh Pemerintahan Belanda. ketika tahun 1830, mereka memaksa para petani untuk menanam komoditas tertentu yang ditetapkan oleh Pemerintahan Belanda (Culturestelse). Kemudian pada tahun tahun 1870, seiring dengan kemenangan kelompok ekonom liberal di Belanda, mereka menerapkan kebijakan Agrarisch Wet, pembukaan investasi bagi pemilik modal swasta di Eropa, menggantikan praktek monopoli yang dilakukan oleh pemerintahan Belanda. sejak saat itu, berdiri perkebunan-perkebunan besar yang dimiliki oleh swasa asing Belanda, seperti perkebunan kopi, teh, gula ataupun kina. (Daliman,. 2001:47)

Para pemodal dari Eropa mendapat suntikan modal dari De Javasche Bank dan menerapkan teknologi modern dan memanfaatkan koneksi internasional. 
Akibatnya, perekonomian pribumi kalah bersaing karena teknologi pribumi masih berskala kecil dan menggunakan peralatan tradisional. Selain itu, terdapat banyak praktek para pedagang asing membeli tanaman yang belum siap panen, dan menjualnya dengan harga tinggi.(Hoesein, 2006 : 506)

Sebab keprihatinan lainnya adalah pada kondisi terjadinya Struktur ekonomi di Jawa pada waktu itu, yang terdiri dari tiga golongan :

a) Golongan kulit putih, yang menguasai perekonomian besar.

b) Golongan orang tionghoa, yang menguasi perdagangan,

c) Adalah orang indonesia yang menguasai pertanian dan perusahaan kecil.

Di tingkat bawah, kelompok pribumi terpinggirkan oleh dominsi kelompok tionghoa. Mereka pada umumnya menguasi perdagangan hingga sampai warung-warung orang indonesia. Pada waktu itu golongn tionghoa dalam sistem ekonomi kolonial sering disebut dengan 'big bussiness' yang berarti pendirian usaha dengan skala modal yang lebih besar(Widjaja d and Swasono, $2002: 144)$

Konsep ekonomi kerakyatan yang dicetuskan oleh para founding fathers bercirikan pada perlawanan terhadap ekonomi kolonialisme. Soekarno dalam pidatonya, memberikan gambaran posisi rakyat indonesia di bawah ekonomi kolonial, yaitu(Moebyarto, 2014 :31):

a) Indonesia diposisikan sebagai pemasok bahan mentah bagi negara-negara industri maju.

b) Indonesia dijadikan 'pasar' bagi produk dari negara-negara industri maju.

c) Indonesia dijadikan tempat untuk memutar kelebihan kapital (modal) yang terdapat di negara-negara industri maju.

Menurut Hatta, Demokrasi Politik tidak laah cukup untuk melaksanakan persamaan dan persaudaraan demokrasi politik, harus pula diikuti dengan demokrasi ekonomi.

Pemikiran demokrasi ekonomi oleh Muhammad Hatta, didasarkan atas semangat kolektivisme dalam masyarakat desa indonesia. Mereka mempunyaihak ulayat atas tanah. Tanah dimiliki secara bersama, sebagai faktor produksi utama dalam masyaraka agaria.(Swasono and Ridjal, 1992 : 144-145). Menurut Hatta, 
demokrasi indonesia terbangun dari desa-desa yang ada di Indonesia, mengandung 3 unsur;musyawarah, kemerdekaan berpendapat, dan tolong menolong (Hoesein , $2006: 513$ )

\section{2) Kemunculan Pemikiran Ekonomi Neoliberalisme}

Paham neoliberalisme tidak dapat dilepaskan dari paham liberalisme. Sebagaimana telah disebutkan di muka, bahwa paham liberalisme merupakan usaha dari kaum berjouis (kelompok menengah) melawan kaum feodal(Huda, 2016 : 31), dalam usaha kepemilikan lahan (faktor industri) yang terpisah dengan kerajaan. Sehingga kemunculan pemikiran liberalisme di bidang ekonomi tak dapat dilepaskan dengan kemunculan industri-industri di Eropa Barat.

Paham liberalisme dianut oleh kolonial, setelah kelompok liberal memenangkan pemilihan dan menguasai parlemen, dan berpengaruh pada kebijakan di Indonesial. Paham liberalisme juga dianut oleh negara-negara Eropa Barat lainnya dan Amerika Serikat. Indonesia sebagai negara jajahan Belanda, merasakan langsung dampak ini. Pada masa liberal, seiring dengan perkembangan perkebunan belanda, memberikan peluang kepada rakyat indonesia untuk menjadi buruh pada sektor perkebunan. Penduduk di Jawa mulai menyewakan lahan-lahan untuk perkebunan belanda. selain di sektor perkebunan, penetrasi terjadi di sektor tekstil yang mematikan kegiatan kerajinan tenun di Jawa.(Daliman,. 2001:55-56)

Kemudian terjadi krisis pada tahun 1930an, yang menyebabkan depresi besar yang melanda dunia. Hingga akhirnya, seorang ekonom Inggris, John Maynard Keynes, mengusulkan pentingnya intervensi negara dalam masalah pengaturan ekonomi. Yang kemudian dikenal dengan nama welfare state (Negara kesejahteraan), dimana negara mempunyai wewenang dalam kepemilikan industri besar, dan kebijakan yang intervensionis terhadap berbagai kegiatan ekonomi. Konsep dasar pemikiran Welfare State adalah negara dituntut untuk memperluas tanggungjawab di bidang sosial ekonomi. (Effendi, 2017 : 172)

Kebijakan Keynesian ini dianut sampai tiga dasawarsa kemudian, sekitar tahun 1960an terjadi krisis ekonomi, yang ditandai dengan berkurangnya keuntungan di bidang investasi swasta, yang berakibat pada terpuruknya 
akumulasi kapital, hingga memunculkan pentingnya menghadirkan kembali paham liberalisme, yang berupa deregulasi, privatisasi perusahaan-perusahaan nasional, dan perlunya peraturan kontrak sektor-sektor tertentu ke pihak swasta. Kemunculan kelompok Pemikir Neoliberalisme di Indonesia, bermula ketika awal mula kekuasaaan Soeharto, kelompok Pemikir yang berorientasi ke Barat dengan pake kebijakan liberalisasi di bidang investasi ini, kemudian dikenal denegan sebutan Mafia Berkeley. (Moebyarto, 2014 : 141)

Sebutan "Mafia" ini karena pemikiran mereka, menjdikan indonesia sebagai boneka Amerika Serikat. sedangkan Berkeley, California, merujuk pada kampus dimana para ekonom neolib tersebut belajar. Kumpulan ekonom ini awalnya dikirim oleh Sumitro Djojohadikusuma ke perguruan tinggi Amerika di Berkeley, California. Ketika kembali, mereka mengajar Ekonomi di Seskoad (Sekolah Staff Angkatan Darat), dimana para murid-murid yang menimba ilmu diantaranya adalah Soeharto, Umar Wirahadikusumah, Muhammad Yusuf, dan Sarbini. (Hadiz, and Dhakidae 2005 ::42)

\section{Analisis Fiqh Terhadap Kemunculan Paham Ekonomi Kerakyatan dan Neoliberalisme}

Kemunculan paham ekonomi kerakyatan dan Neoliberalisme sebagaimana di atas didasarkan atas kebutuhan. Jika liberalisme dan neoliberalisme merupakan kebutuhan dari para investor untuk memperluas pangsa usaha, dan meminimalisir kerugian, paham kerakyatan diperjuangkan oleh sekelompok tokoh, seperti Muhammad Hatta di masa kemerdekaan, kemudian dilanjutkan dengan Prof Moebyarto, mereka mendasarkan diri akan pentingnya proteksi atau perlindungan atas usaha yang dikelola oleh orang banyak.

Antara paham Liberalisme dan Kerakyatan, merupakan dua model ekonomi, yang keduanya berdasarkan atas pandangan hidup sekular. Yang satu terfokus pada pandangan hidup (worldview) tentang kebebasan manusia, sedangkan yang satu berpijak pada nilai-nilai filanthropi. Bahwa pada diri seseorang terdapat sisi kebajikan yang harus diberikan kepada orang lain. Nilainilai ini ada pada diri tiap seseorang. Selain itu, paham ekonomi kerakyatan, 
adalah paham turunan dari paham sosialisme, sebagai reaksi atas kepemilikan faktor produksi di tangan segelintir orang. Baik paham sosialisme, liberalisme, maupun paham ekonomi kerakyatan (democratic economy) tidak lah melandaskan diri pada acuan agama tertentu, dan bebas dari nilai-nilai ketuhanan.

Hal ini berbeda dengan syariat islam, dimana world view dalam syariat adalah Tauhid. Dimana perilaku ekonomi didasarkan pada ketertundukan pada Allah, sebagai satu-satunya Pencipta dan Berkuasa atas segalanya. Oleh karena itu, prinsip Ekonomi paling mendasar dalam islam adalah pernyataan bahwa segala sesuatu adalah milik Allah semata. kepemilikan seseorang atas sesuatu bukan lah mutlak, melainkan kepemilikan semu.

Meskipun demikian, terdapat beberapa 'kesamaan' antara islam dengan ekonomi kerakyatan. Karena nilai ketuhanan sebagaimana yang tertuang dalam al Qur'an maupun yang dicontohkan oleh Nabi, mengarahkan ke bentuk perekonomian yang adil dan distribusi kekayaan yang merata dan dapat dinikmati oleh semua pihak. Bahkan perilaku pengumpulan harta tanpa batas, hanya didasarkan pada insting, dikategorikan oleh agama dengan istilah al Humazah, yaitu perilaku yang suka menuruti insting dengan mengumpulkan banyak harta dan menghitung nilai-nilai investasi yang dimilikinya.

Islam menekankan bahwa seeorang individu tidak boleh membahayakan orang lain. Prinsip ini juga semestinya berlaku pada masalah ekonomi. Prinsip ini berpijak pada hadits Rasulullah:

$$
\text { لا ضرر و لا ضرار، من ضار ضاره الله، ومن شاق شق الله عليه }
$$

Tidak diperbolehkan untuk memberkan kesusahan kepada diri sendiri, dan tidak diperbolehkan menyusahkan orang lain. Dan barang siapa memberi kesusukan kepada orang lain, maka Allah akan memberkan kesusahan kepadanya. Dan barangsiapa memberi beban kepada orang lain, maka Allah akan memberkan beban kepadanya. (HR Daruquthni dalam Kitab Bulughul Maram Hadits ke 910)

Lafazh dari hadits di atas adalah 'aam (umum) dapat meliputi apa saja. Pertanyaannya apakah hal ini juga berlaku pada dagang? Karena kehadiran seorang pedagang akan mengurangi 'porsi' bagi pedagang yang lain, dan hal ini 
adalah hal yang wajar. Tetapi permasalahannya, bagaimana jika pedagang itu akan 'merusak pasaran', dengan biaya murah dan barang yang bermutu lebih baik? Para ulama madzhab berselisih pendapat, sebagian menolak intervensi pasar, sedangkan ulama lainnya membolehkannya, seperti Ibn Taimiyyah.(Taimiyyah, $1976: 25)$

Fatwa sebagian ulama yang melarang intervensi pemerintah, tidak bisa dipahami bahwa mereka sebagai pendukung neoliberalisme. karena prinsip liberalisme lain seperti penolakan terhadap pemberian subsidi jelas berbeda dengan prinsip islam. dimana dalam prinsip islam, proteksi pemerintah terhadap orang miskin dan faqir diberikan tempat prioritas lewat Baitul Maal.

Selain terdapat korelasi antara riwayat-riwayat dari hadits Nabi maupun sahabat, sejumlah tokoh penggerak ekonomi kerakyatan yang ada di Indonesia kebetulan beragama islam. Seperti Oemar Said Tjokroaminoto yang mengarang buku Sosialisme Islam, Muhammad Hatta, ir. Soekarno, Prof Moebyarto, Adi Sasono, Ekonom Dr Rizal Ramli, dan Dr Ihsanudin Noorsy.

\section{c. Landasan Yuridis Ekonomi Kerakyatan dan Neoliberalisme}

\section{1). Landasan Ekonomi Kerakyatan}

Pada dasarnya, sistem ekonomi yang dianut oleh Indonesia berdasarkan landasan yuridis adalah ekonomi kerakyatan. Hal ini dapat dilihat dari Alinea keempat Pembukaan UUD 1945 yang berbunyi ”...Kemudian daripada itu untuk membentuk suatu Pemerintahan Negara Indonesia yang melindungi segenap bangsa Indonesia dan seluruh tumpah darah Indonesia danuntuk memajukan kesejahteraan umum,..".

Pada Pasal 27 ayat 2, dijelaskan bahwa "Setiap warganegara berhak mendapatan pekerjaan dan penghidupanyang layak bagi kemanusiaan', dan di pasal 34, menyatakan bahwa Fakir misin dan anak terlantar dipelihara oleh Negara. melalui dua ayat ini, jelas bahwa negara harus melakukan banyak intervensi ekonomi, yang memungkinkan pemenuhan hak-hak warganegara diatas bisa direalisasikan. 
Singgih Muheramtohadi

Terkait dengan penguasaan SDA (Sumberdaya Alam), diatur dalam pasal 33 ayat 2-3 menjelaskan tentang peranan negara dalam sistem ekonomi, yaitu meliputi;

a. Cabang-cabang produksi yang penting bagi negara dan yang menguasai hajat hidup orang banyak dikuasai oleh negara;

b. Bumi, air, dan segala kekayaan yang terkandung didalamnya dikuasai oleh negara dan dipergunakan bagi sebesar-besarnya kemakmuran rakyat.

Pada pasal 33 ayat 1 dinyatakan bahwa 'Perekonomian disusun sebagai usaha bersama atas asas kekeluargan', menurut Sri Edi Swasono, 'perekonomian' yang dimaksud pada frase tersebut meliputi keseluruhan usaha ekonomi: baik formal maupun non formal, ekonomi rakyat, BUMN, swasta maupun koperasi. Kesemuaya dsusun sebagai 'usaha bersama' berdasar asas kekeluargaan atau brotherhood. Sedangkan arti kata 'disusun' adalah ditata sedemikian rupa dengan sengaja, bukan dibiarkan mengikuti kehendak pasar. (Mubyarto dkk, : 155)

\section{2) Landasan Yuridis Paham Ekonomi Liberal}

Kebijakan Neoliberalisasi terwujud pada kebebasan investasi, termasuk investasi asing, misalnya tentang Undang-undang Penanaman Modal Asing (PMA) Nomor 1 tahun 1967, kemudian disempurnakan kembali pada Undangundang No. 25 tahun 2007, yang salah satu isinya adalah ditiadakannya pembedaan antara investasi dari luar negeri maupun dalam negeri sebagaimana yang terlihat pada pasal 6 ayat 1 berikut ini;

Pemerintah memberikan perlakuan yang sama kepada semua penanam modal yang berasal dari negara mana pun yang melakukan kegiatan penanaman modal di Indonesia sesuai dengan ketentuan peraturan perundang-undangan.

Sektor investasi pun meliputi segala hal tidak hanya di bidang pertambangan dan perminyakan. Semua sektor bisa dimasuki oleh investor asing, kecuali bagi sektor-sektor yang berhuubungan dengan persenjataan, mesiu, alat 
peledak dan peralatan perang (Pasal 12 ayat 1 UU No. 25 tahun 2007). Sehingga, investor asing dapat menanamkan modalnya bersaing dengan pasar tradisional, toko klontong, atau bersaing di bidang pertanian dan perkebunan. ingga, investor asing dapat menanamkan modalnya bersaing dengan pasar tradisional, toko klontong, atau bersaing di bidang pertanian dan perkebunan. Sedangkan di sektor pertambangan keluar Peraturan Pemerintah (PP) Nomor 21 Tahun 1970 yang berisi tentang Hak Pengelolaan Hutan, yang berorientasi pada kegiatan eksplorasi sumberdaya kehutanan oleh pihak korporasi.

Kbijakan tentang kemudahan investasi juga dilanjutkan oleh Presiden Jokowi, dengan memangkas berbagai prosedur yang menyulitkan investor, dan memberikan kemudahan bagi TKA asing untuk bekerja di segala sektor di Indonesia, dengan terbitnya Perpres tahun 20 tahun 2018, serta menerbitkan beberapa peraturan untuk memudahkan investasi.

\section{3) Analisa Landasan Yuridis berdasarkan Fiqh}

Landasan Yuridis merupakan hasil kesepakatan para pembuat perundangundangan. Yaitu kelompok BPUPKI yang membuat Undang-undang Dasar 1945, termasuk pada bagian pembukaan UUD 1945, dan Pancasila. Sedangkan Landasan Yuridis bagi paham Liberal, didasarkan atas Undang-undang Penanaman Modal asing, yang diajukan oleh Presiden Soeharto kemudian disahkan oleh MPRS. Kemudian menyusul dengan berbagai perundang-undangan yang memungkinkan terjadinya peningkatan di bidang investasi, kebijakan deregulasi dan privatisasi sejumlah BUMN.

Landasan Yuridis yang dipakai dalam kebijakan pro rakyat adalah didasarkan ats UUD 1945 (terutama sila ke 27, 33 da 34) dan Pancasila terutama pada Sila ke 5. Merupakan landasan Yuridis yang sangat dekat dengan ajaran islam. tentang pentingnya jaminan atas keadilan dalam distribusi ekonomi ini dapat dilihat pada Surat Al Hasyr ayat 7

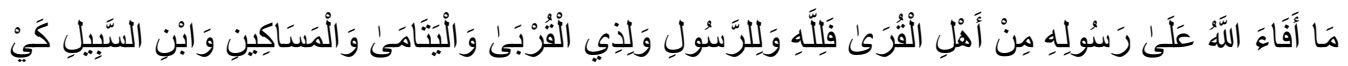

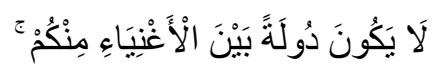


Apa saja harta rampasan yang diberikan Allah kepada RasulNya (dari harta benda) yang berasal dari penduduk kota-kota maka adalah untuk Allah, untuk Rasul, kaum kerabat, anak-anak yatim, orang-orang miskin dan orang-orang yang dalam perjalanan, supaya harta itu jangan beredar di antara orang-orang kaya saja di antara kamu.

Meskipun ayat di atas tentang pembagian fa'i atau harta rampasan, tetapi kaedah pokok dari pembagian fai itu adalah mewujudkan peredaran distribusi kekayaan yang adil, terutama bagi kelompok-kelompok rentan. Ini lah sesuai dengan pasal 34 UUD 1945 bahwa orang miskin dan anak terlantar dipelihara oleh Negara. dan sumber pemasukan negara, salah satunya dengan penguasaan terhadap sektor yang menguasai hajat hidup orang banyak.

\section{d. Kebijakan-kebijakan Pro Rakyat vs Pro Kapital}

\section{1). Kebijakan Berlandaskan Paham Ekonomi Kerakyatan}

Pertama kali kebijakan ekonomi yang dilakukan oleh Ir. Soekarno adalah menanggulangi masalah ekonomi yang mendesak, seperti masalah produksi pangan dan distribusi makanan, serta permasalahan sandang. Kebijakan itu ditempuh hampir berbarengan dengan kebijakan Ir. Soekarno lainnya, yaitu melakukan nasionalisasi terhadap beberapa perusahaan Belanda, seperti De Javase Bank dan Nederlandche Handel Maatchappaij/NHM). Kedua perusahaan ini, yang punya peran penting dalam monopoli perdagangan hasil perkebunan (karet, kina, kopi, teh, tembakau, vanili dan sebagainya) pasar Eropa.(Sukarsa, 2010 :1)

Gagasan di bidang pangan dikenal denagn Nama Kasimo Plan. Kasimo merupakan nama Menteri yang menjabat urusan makan. Permasalahan yang dihadapi negara waktu itu adalah kosongnya kas negara, dan pendapatan dari pajak dan bea masuk yang sangat berkurang. Selain itu masyarakat indonesia juga menghadapi permasalahan makan, karena berkurangnya produksi dan distribusi bahan makanan. Usaha untuk menyelesaikan hal itu adalah dengan ;

a) Melakukan penanaman atas tanah kosong dan tidak terurus di Sumatera bagian Timur. 
b) Melakukan intensifikasi pertanian di jawa, dengan memperbanyak varietas bibit unggul

c) Transmigrasi bagi 20 juta penduduk jawa dipindahkan ke sumatra dalam jangka waktu 10-15 tahun.

banyakkebijakan yang ditempuh oleh Ir. Soekarno berdasarkan paham kerakyatan. Pada waktu demokrasi terpimpin, Soekarno mencanangkan sistem sosialisme indonesia yang dijalankan sebagai berikut :

a) Dalamkegiatan produksi, dilakukan oleh negara maupun swasta, dan ditujukan untuk kepentingan rakyat, terutama bahan pokok

b) Kegiatan produksi harus melalui campur tangan negara, untuk memastikan produksi dapat didistribusikan kepada rakyat secara merata.

c) Mendorong kegiatan ekonomi dan industri dari eksport bahan mentah menjadi barang jadi, sehinga dapat meningkatkan lapangan pekerjaan bagi rakyat dan menambah keuntungan bagi negara.

d) Kegiatan import hanya ditujukan bagi komoditas yang dapat menambah produksi dalam negeri. Sehingga, kesempatan kerja naik, dan import berkurang, sehingga meminimalisir biaya.

e) Negara harus memulai pembangunan industri dari sektor huulu, agar negara tidak tergantung dengan sumber dari luar negeri

f) Dengan sistem yang terbangun di atas, maka akan terjadi pembangunan ekonomi yang dapat mewujudkan cita-cita masyarakat yang sama rasa dan sama rata.(Toto, Rahardjo, and Herdianto 2001 :174-176)

Upaya membangun sistem sosialisme indonesia itu berhenti, dengan berbagai krisis yang menerpa indonesia pada dekade 1960an. Munculnya inflansi sangat tinggi, disertai dengan berkurangnya kebutuhan kebutuhan pokok. Kemudian muncul nya peristiwaG30S PKI, yang memaksa Presiden Soekarno lengser dan digantikan oleh Soeharto.

Jika sebelumnya, Soekarno menerapkan Ekonomi Berdikari, sebagaimana dijelaskan beberapa point di atas, hal ini kontras dengan apa yang dilaukan oleh Soeharto. Ia langsung membuat Undang-undang Penanaman Modal Asing (UU PMA) pada tahun 1968, yang memungkinkan investor asing dapat menanamkan 
modalnya di Indonesia. Tetapi, sebelum masa kejatuhan Soeharto di tahun 1998, Presiden Soeharto membuat kebijakan yang pro rakyat (Ekonomi Kerakyatan), dengan nama Program Jaring Pengaman Sosial, yang meliputi;

a) Peningkatan ketahanan pangan

b) Menciptakan lapangan kerja yang produktif

c) Pengembangan usaha kecil dan menengah (UMKM)

d) Perlindungan sosial dalam pelayanan kesehatan dan Pendidikan.

Kebijakan ini mengeluarkan anggaran 18 Triliun rupiah yang dibagi menjadi 17 sektor pembangunan. (Sukarsa, $2010: 4$ )

Pada zaman SBY digalakkan program KUR (Kredit Usaha Rakyat), dengan memberi suntikan kepada PT Askrindo dan Perum Jamkrindo) sebagai perusahaan penjaminan modal bagi program KUR. Program ini digalakkan pemerintah, dengan pertimbangan banyaknya UMKM yang memiliki potensi tetapi tidak memeuhi persyaratan teknis perbankan. Atau berusaha memberi kemudahan bagi peminjaman kredit. Banyak kebijakan SBY di bidang pemberdayaan ekonomi rakyat, dengan memberikan suntikan dana, baik lewat cara pemodalan maupun dengan hibah. Misalnya, program LM3 yang memberikan bantuan kepada usaha-usaha yang dimiliki Pesantren dan gereja yang berjumlah ribuan, beserta program pemberian bantuan kepada Gapoktan (Gabungan kelompok Petani). Meskipun di sisi lainnya, pemerintah SBY juga menerapkan kebijakan yang memudahkan para investor asing untuk masuk sampai tingkat daerah.(Hoesein, 2006 :518)

\section{2)Kebijakan Berdasarkan Paham Neoliberalisme}

Dasar ekonomi yang dicita-citakan oleh para founding fathers, sebagaimana telah disebutkan, adalah berdasarkan kekeluargaan. Dalam asas kekeluargaan, maka 'nurani' ditempatkan sebagai jantung ekonomi. Berbeda sama sekali dengan sistem liberal. Munculnya Soeharto sebagai pemimpin Republik Indonesia, membawa perekonomian indonesia , 'melenceng' dari sebelumnya.

Soeharto melandaskan diri pada sektor pertumbuhan ekonomi, dengan indikator keberhasilan ekonomi pada kenaikan PDB (Produk Domestik Bruto), yang 
merupakan suatu total dari nilai barang dan jasa yang dihasilkan oleh suatu negara dalam satu tahun. untuk meningkatkan PDB ini lah, maka jalan satu-satunya adalah meningkatkan investasi.

Menurut Dawam Rahardjo, langkah konkret yang dilakukan oleh Soeharto di bidang ekonomi adalah(Umaya, 1995:55)

a) Pembukaan perdagangan internasional, yang memungkinkan membnjirnya barang-barang dari luar negeri, seperti barang elektronik dan motor dari Jepang. Salah satu cara untuk menarik investor tersebut adalah dengan mengurangi pajak masuk dan proteksi terhaap barang import. Kebijakan import oleh Orde Baru dibutuhkan untuk mencukupi permintaan dalam negeri.

b) Untuk meredam inflansi dari meningkatnya permintaan terhadapbarang import, maka diperlukan devisa negara. jalan satusatunya adalah dengan melakukan pinjaman luar negeri.

c) Pembukaan pintu bagi modal asing. Termasuk pada penanamanmodal bagi pertambangan oleh PT Freeport, pemberian kontrakterhadap industri perminyakan dari luar negeri.

Di bidang pengelolaan hutan, misalnya, pemerintah menerbitkan Peraturan Pemerintah (PP) Nomor 21 tahun 1970 tentang HPH (Hak Pengelolaan Hutan) dan HPHH (Hak Pemungutan Hasil Hutan), dengan keluarnya peraturan ini, maka hutan dieksploitasi secara besar-besaran hingga menghasilkan keuntungan 2,5 Milyar Dollar per tahun, dengan pembagian hasil ke negara hanya sebesar $17 \%$ dan sisanya untuk korporasi pemegang HPH. Terdapat 12 Group Perusahaan yang terdiri dari 109 perusahaan yang menguasai sebagian besar pengelolaan hutan di Indonesia, melakukan eksploitas demi keuntungan pribadi, menyebabkan kerusakan hutan. (Hidayat, $2015: 34$ ).

Angka pertumbuhan ekonomi yang diinginkan oleh Soeharto memang terealisasikan, yaitu tumbuh di atas $6 \%$ tiap tahun, tetapi hal ini menimbulkan ketidakpuasan di kalangan akademisi, karena pertumbuhan ekonomi tidak 
dibarengi dengan pemerataan pendapatan. Arief Budiman, misalnya, mengkritik kebijakan ekonomi yang ditempuh oleh Soeharto adalah metode Pragmatis, tanpa mengetahui jelas kemana arah tujuannya.(Budiman 1982 :15)

Kelonggaran dalam hal investasi yang diberikan oleh pemerintah kepada para investor asing ini lah yang memunculkan banyak kekhwatiran. Kemudian memunculkan gerakan yang terakumulasi pada gerakan MALARI pada tanggal 14 Januari 1974.

Periode kejayaan Orde Baru bukan didapatkan dari kebijakan investasi luar negerinya. Banyak pengamat menilai, keberhasilan pembangunan ekonomi terletak pada melonjaknya harga minyak dunia, atau sering disebut dengan Oil Boom. Produksi minyak indonesia pada tahun 1980 mencapai 1,5 juta barel per hari (bph), dengan harga minyak 15 dollar AS . Pada waktu ini, kontribusi minyaksebesar $62-67 \%$ dari pendapatan negara. pada waktu oil boom ini dapat menigkatkan pertumbuhan ekonomi sebesar 7,8\% (Nugroho : 5)

Bentuk kebijakan liberalisasi lainnya oleh Orde Baru adalah dengan diterbitkannya UU No. 25 tahun 1997, yang berisi kontrol terhadap aktivitas buruh, termasuk dalam hal penyatuan organisasi buruh. Tujuan dari kontrol terhadap buruh ini, dalah untuk memastikan proteksi bagi jalannya investasi. Gaji buruh yang rendah dan diamnya buruh, merupakan salah satu tawaran yang menarik bagi investor luar, untuk mengembangkan modal di indonesia.

Sedangkan kebijakan neoliberalisme, selain ditentukan oleh faktor internal, juga dipengaruhi oleh tekanan eksternal. Misalnya, pada tahun 1995, WTO menekan pemerintah untuk mengurangi subsidi di sektor pertanian, di tengah ketergantungan petani oleh pupuk kimia dan pestisida. WTO juga menekankanuntuk melakukan langkah liberalisasi di bidang perdagangan, yang mengakibatkan masuknya investsi asing pada bidang pertanian. Akhirnya, sektor pupuk kimia dan pestisida, dikuasai oleh perusahaan asing. (Nugroho, $2017: 7$ )

Beberapa bentuk kebijakan liberalisme lainnya adalah pemberian kewenangan tertentu (privilege) kepada perusahaan-perusahaan besar, yang berpotensi menguntungkanperusahaan dan merugikan akses masyrakat umum. Seperti pemberian wewenang kepada PT Bogsari untuk mengimpor dan 
menggiling teung terigu dalam negeri. Melalui kebijakan tersebut, menguasai secara penuh perdagangan tepung terigu, dan menetapkan harga secara semenamena. (Nugroho 2017 : 7-8)

Sesudah lengsernya Soeharto, pemerintahan Transisi Habibie, dan Presiden Terpilih Abdurrahman Wahid (lewat polling di DPR/MPR) fokus pada kebijakan pemulihanekonomi. Baru pada masa Megawati yang menggantikan Gus Dur, membuat kebijakan yang dianggap sebagian masyarakat sangat kontroversial, seperti penjualan Indosat ke Temasek, diikuti dengan langkah pengurangan segala bentuk subsidi yang membuat harga-harga kembali naik, dan rupiah kembali merosot. Dan pencabutan segala tarif import, yang memungkinkan indonesia sebagai kawasan pasar bebas di Asia Tenggara. Di Era Megawati diterbitkan UU Migas No. 22 Tahun 2001 \& UU No. 7 tahun 2004 , yang memungkinkan swasta (termasuk asing) dapat mengelola Migas dan sumberdaya air di Indonesia. (Wibowo, 2010 :133)

Kebijakan privatisasi ini berpijak pada pemikiran bahwa menyerahkan kegiatan ekonomi pada sektor yang strategis ke negara adalah tindakan yang siasia. Lebih efektif, jika sektor tersebut ditangani oleh pihak swasta, karena lebih mampu menjamin efektivitas usaha. Dengan privatisasi BUMN tidak lah merugikan rkyat banyak, justru dengan pemberian akses seluas-luasnya kepada investor, akan meningkatkan kesejahteraan rakyat, karena dengan demikian, maka semua SDM akan bersaing, sehingga memunculkan banyak komodita dengan mutu tinggi, dengan harga terjangkau, hasil dari persaingan tersebut.

Kebijakan megawati pada waktu itu dianggap oleh beberapa pengamat ekonomi bercirikan pada kebijakan yang sangat patuh kepada IMF, dan berhasil melakukan privatisasi pada aset strategis negara, lainnya, seperti BNI, PT Batu Bara Bukit Asam, Kimia Farma, Indofarma, Angkasa Pura, dan sejumlah BUMN lainnya. padahal BUMN tersebut mempunyai prospek yang sangat baik, dan dijual dengan harga yang relatif murah.

Di antara berbagai kebijakan privatisasi tersebut, yang paling banyak disorot adalah kebijakan penjualan Indosat, karena indosat terkait dengan masalah keamanan komunikasi. Dengan dijualnya indosat, maka wajar jika muncul 
kekhawatiran di sejumlah pihak, akan kedaulatan negara, dalam masalah kontrol dan mengetahui berbagai sistem keamanan jaringan komunikasi yang ada di ndonesia. Sejumlah rahasia negara pun dikhawatirkan akan mudah dicuri oleh singapura lewat Temasek.

Kebijakan Neolib ini kemudian diikuti oleh SBY, dengan penghapusan hak monopoli minyak ke Pertamina, dan membuka investasi minyak pada sektor hilir, yang memungkinkan swasta untuk bersaing di pasaran. Karena tuntutan persaingan pasar, maka tidak memungkinkan adanya subsidi di sektor hilir migas, sehingga pemerntah mencabut subsidi BBM, dan terjadinya kenaikan BBM.

\section{3) Pandangan Islam Terhadap Kebijakan Ekonomi}

Tidak semua kebijakan ekonomi oleh suatu rezim tertentu, adalah kebijakan neolib sepenuhnya, ataupun kebijakan yang berorientasi kerakyatan sepenuhnya. Misalnya zaman SBY, ia meratifikasi Pasar Bebas Asia Tenggara, tetapi kebijakan subsidi, dari subsidi pupuk, subsidi kewirausahaan, maupun Bantuan Sosial (Bansos) ia galakkan..

Terkait dengan masalah privatisasi pada sektor-sektor yang vital bagi negara, islam menekankan adanya jaminan bagi semua lapisan masyarakat dalam mengaksesnya. Dan ini secara implisit tidak memungkinkan dikuasai oleh sektor swasta.

Sebagaimana sabda Nabi berikut ini "Manusia berserikat dalam tiga hal, yaitu padang rumput, air dan api" (HR. Abu Dawud dan Ahmad) . jika kita menafsirkan hadits nabi itu secara kontekstual, maka

a) Padang rumput, merupakan suatu hal yang langka di daerah gurun. Keberadaan padang rumput sangat berarti bagi para penggembala. Tidak memungkinkan kepemilikan pribadi atas padang rumput ini.

b) Air, keberadaan air di daerah gurun berada di titik-titik tertentu yang dinamakan dengan oase. Selain itu, juga terdapat beberapa sumur, yang sumber nya berasal dari bawah tanah. Kepemilikan pribadi atas sumur, berarti kepemiliikan pribadi atas sumber air, hal ini lah yang dapat menjadi gejolak masyarakat. peristiwa ini,dapat kita jumpai pada pembelian sumur oleh Utsman dari seorang Yahudi di Madinah. Hadits ini mengandung dua makna, yaitu 
pertama, mengandung makna yang berisi kenyataan bahwa air, api dan padang rumput adalah suatu hal yang selama ini menjadi ikatan antar semua orang. Kedua, bahwa sumber-sumber itu tidak dimungkinkan dimiliki perseorangan.

Kebijakan privatisasi Indosat tidak memungkinkan, karena sangat penting bagi keamanan bangsa Indonesia. Semangat yang dimiliki oleh perusahaan kapital adalah menciptakan profit sebesar-besarnya (sebagaimana umumnya tujuan dasar dalam manajemen usaha), dan jika hal ini tidak dibatasi, maka akan muncul pribadi-pribadi yang rakus dengan harta. Dan kerakusan ini, akan berdampak pada tatanan sosial. Padahal dalam kaedah dasar ekonomi al Qur'an adalah distribusi ekonomi, sampai ke tingkat paling bawah sekalipun (faqir miskin dan anak terlantar). Dan hal ini tidak bisa dijangkau dalam masyarakat kapitalistik. Memang ada, CSR (Corporate Social Responsibility), tetapi angka CSR sangat kecil untuk menanggulangi kemiskinan sistemik. Begitu juga dengan pendapatan negara yang dihasilkan dari sektor pajak. Realitasnya, rasio pajak kita sangat kecil, yaitu sebesar 11\% dari total PDB. (Detik Finance, 23 Nov 2017)

Kelemahan dari fiqh klasik pada bidang ekonomi, tidak membahas detail tentang perlunya proteksi usaha kecil dari persaingan dengan pedagang besar. Padahal terdapat beberapa sumber hukum yang bisa dijadikan rujukan, seperti permintaan Umar kepada salah seorang untuk menaikkan dagangannya, jika tidak maka ia akan diusir dari pasar (HR Abu Dawud). Hal ini juga bisa dijadikan dasar bagi para ekonom muslim, untuk meneguhkan kembali pentingnya proteksi bagi usahawan kecil, dari persaingan yang tidak seimbang dengan perusahaan raksasa.

Seperti menjamurnya swalayan akan mematikan toko klontong. Dan adanya Jasa Ojek Online dapat menggusur jasa ojek tradisional. Karena mereka mempunyai perangkat dan manajemen yang sangat bagus, yang memungkinkan memenangkan persaingan dan menyingkirkan usaha-usaha yang sebelumnya dirintis oleh perseorangan.

Sulit untuk mengembalikan indonesia kepada sistem ekonomi kerakyatan sebagaimana amanat UUD 1945. Walaupun, hal ini adalah kewajiban bagi seorang muslim untuk menegakkan nilai keislaman dalam kehidupan berbangsa dan bernegara. Karena ekonomi kerakyatan adalah sangat dekat dengan islam, 
karena dasar yang dipakai hampir sama, yaitu hati nurani dan prinsip agama. Dimana keduanya hampir berdekatan, karena nurani (sebagai dasar ekonomi kerakyatan) adalah bagian dari agama islam.

\section{Kesimpulan}

Paham Ekonomi Kerakyatan dan Ekonomi Neoliberalisme merupakan dua paham ekonomi yang saling menegasi. Ekonomi kerakyatan berpangkal pada perlawanan terhadap paham liberalisme, dan dipengaruhi oleh paham sosialisme. Keduanya mempunyai tokoh pemikir, yang punya pengaruh besar dalam tiap pengambilan keputusan yang berkaitan dengan ekonomi pada suatu rezim pemerintahan. Perdebatan paham Kerakyatan dan Neoliberalis diwakili oleh perdebatan antara Dr Rizal Ramli dengan Dr Sri Mulyani. Keduanya mempunyai pengaruh, baik di kalangan akademisi maupun di kalangan pengambil kebijakan publik.

Secara umum, Ekonomi Kerakyatan adalah ekonomi yang dituangkan dalam dasar bernegara kita, maupun dalam falsafah negara, khususnya pancasila sila ke 5. Kedua nya harus menjiwai semua produk perundang-undangan. Tetapi, kemunculan produk perundangan yang berlawanan dengan UUD 1945 dan Pancasila, terjadi akibat kebijakan Soeharto. Kondisi ekonomi waktu kejatuhan Soekarno memang dalam kondisi terpuruk, dan wajar jika rezim mencari solusi untuk mengatasi keadaan. Tetapi solusi ini hanya bersifat pragmatis, dan hanya mampu menjawab permasalahan sementara, dengan meninggalkan berbagai permasalahan besar, terutama di bidang proteksi usaha kecil, kedaulatan ekonomi danpemerataan ekonomi.

Akhirnya indonesia terjebak dalam tekanan-tekanan yang pihak lembaga kreditur internasional, IMF dan World Bank, yang selalu menekan pemerintah untuk melakukan beberapa paket kebijakan, terutama kebijakan pembukaan pasar bebas, pencabutan subsidi dan Privatisasi aset nasional (BUMN).

Jatuhnya indonesia untuk mengikuti pola ekonomi Neolibeal ini merupakan suatu keadaan yang tidak hanya bisa dipecahkan lewat mengkaji pandangan fiqh, tetapi harus benar-benar membutuhkan keberanian dari pihak 
pengambil keputusan publik untuk melawan tekanan dari asing. Karena pandangan fiqh terkait ekonomi sangat jelas, yaitu;

a. Obyek vital yang menguasai hajat orang banyak, atau penting, tidak bisa dimiliki oleh swasta.

b. Ekonomi bukan lah bidang bebas nilai sebagaimana dalam paham ekonomi neoliberal, tetapi ia penuh nilai. Dalam islam, ekonomi harus berpijak pada sendi tauhid dan berasaskan kejujuran. Usaha ekonomi yang didasarkan kerakusan dan menyebabkan kerugian orang banyak, merupakan hal terlarang dalam agama.

c. Negara mempunyai hak untuk mengatur ekonomi, untuk memastikan seluruh lapisan masyarakat mempunyai akses terhadap sumber kekayaan. Artinya, pemerintah diwajibkan untuk melakukan perlindungan terhadap kelompok rentan, baik diwujudkan lewat subsidi ataupun berbagai kemudahan lainnya. Dan bentuk-bentuk proteksi ini terlarang dalam mazhab ekonom Neoliberal.

Sehingga, jika ditinjau secara fiqh, paham Neoliberalisme adalah paham merusak dan kebanyakan entrypoint pemikirannya bertentangan dengan prinsip ekonomi islam. sedangkan di sisi lainnya, fiqh iqtishodiy banyak berkesesuaian dengan paham ekonomi kerakyatan. Beberapa sebab kesesuaian tersebut adalah;

a. Ekonomi kerakyatan didasarkan atas prinsip nurani, dan etika ekonomi islam banyak menekankan aspek nurani. Seperti kejujuran, kepedulian, dan sebagainya.

b. Dilihat dari latar belakang sejarahnya, para pemikir ekonom kerakyatan yang ada di Indonesia, kebanyakan adalah berasal dari kelompok muslim. Seperti Mohd. Hatta, Tjokroaminoto, Rizal Ramli, Moebyarto, dan sebagainya.

c. Antara Ekonomi Kerakyatan dan Ekonomi Islam, mempunyai 'musuh bersama; yaitu paham Neoliberalisme. 
Singgih Muheramtohadi

\section{DAFTAR PUSTAKA}

Bhudianto, Wahyu, (2012). Sistem Ekonomi Kerakytan Dalam Globalisasi Perekonomian. Transformasi Vol.XIV No 22: 1-9.

Budiman, Arif (1982) Arief Budiman, "Sistem Perekonomian Pancasila, Kapitalisme Dan Sosialisme. PrismaVol I Januari

Daliman., A. ( 2001) Sejarah Indonesia Abad 19- Awal Abad 20. Yogyakarta: FIS UNY.

Effendi, Winda Roselina (2017) Konsep Wellfare State Di Indoneisa. Jurnal Trias Politica V o 11 . N o. 1: 171-183.

Faqih, Mansour, (2003). Bebas Dari Neoliberalisme. Yogyakarta: Insistnet.

Hadiz, Vedi R., and Daniel Dhakidae, (2005), Social Science And Power In Indonesia. Singapore: Equinox Publishing.

Hidayat, Herman ( 2015), Pengelolaan Hutan Lestari: Partisipasi, Kolaborasi Dan Konflik. Jakarta: Yayasan Obor.

Hoesein, Zainal Arifin, ( 2006), Peran Negara Dalam Pengembangan Sistem Ekonomi Kerakyatan Menurut UUD 1945. Jurnal Hukum IUS QUIA IUSTUM NO. 3 VOL. 23.

Huda, Choirul. (2016)Ekonomi Islam Dan Kapitalisme (Merunut Benih Kapitalisme Dalam Ekonomi Islam). Economica Volume VII/Edisi 1: 2749.

Moebyarto. ( 2014), Ekonomi Kerakyatan,. Muhammad Ridwan, ed. Jakarta: Lembaga Suluh Indonesia. 
Nugroho, Wahyu Budi (2017) Konstelasi Ekonomi, Sosial Dan Politik Di Era Orde Baru*. In .

Saphiro, Ian. ( 2006), Evolusi Hak Dalam Teori Liberal. Masri Maris, tran. Jakarta: Yayasan Obor.

Suharto, Ugi ( 2004) (Sosialisasi Ekonomi Islam dalam Conventional Economic Paradigm in Socializing Islamic Economics] In Journal of the Islamic Economic Forum for Indonesian Development (ISEFID Review Vol. 3 No.3: 40-61.

Sukarsa, I Made (2010) Perkembangan Ekonomi Kerakyatan Di Indonesia1. In .

Swasono, Sri Edi, and Fauzie Ridjal (1992), Mohammad Hatta, Demokrasi Kita, Bebas Aktif, Ekonomi Masa Depan, Jakarta: UI Press.

Taimiyyah, Ibn, ( 1976), Al-Hisbah Fi Al-IslâM. Kairo: Dar Al Sya’b.

Taqwa, Ridhah, ed. (2008), Ekonomi Dan Politik, Sosial Dan Humaniora. Yogyakarta: Himpunan Mahasiswa Pascasarjana, Universitas Gadjah Mada.

Toto, Iman, K Rahardjo, and WK Herdianto, ( 2001), Bung Karno Dan Ekonomi Berdikari, Kenangan 100 Tahun Bung Karno. Jakarta: Grassindo.

Umaya, Faraz, ed. ( 1995), Liberalisasi Ekonomi, Pemerataan Dan Kemiskinan. Yogyakarta: Tiara Wacana. 
Singgih Muheramtohadi

Wibowo, I (2010), Negara Centeng: Negara Dan Saudagar Di Era Globalisasi. Yogyakarta: Kanisius.

Widjaja d, Wangsaan, and . Meutia F Swasono, ( 2002)..Kumpulan Pidato II,Dari Tahun 1951 s.d 1979,. Jakarta: Toko Gunung Agung. 